\title{
Wood Density of Ten Native Trees and Shrubs and Its Possible Relation with a Few Wood Chemical Compositions
}

\author{
Ratikanta Maiti ${ }^{1}$, Humberto Gonzalez Rodriguez ${ }^{1}$, Aruna Kumari ${ }^{2}$ \\ ${ }^{1}$ Facultad de Ciencias Forestales, Universidad Autónoma de Nuevo León, Linares, México \\ ${ }^{2}$ Agricultural College, Professor Jaya Shankar Telangana State Agricultural University, Jagtial, India \\ Email: ratikanta.maiti@gmail.com, humberto.gonzlez@uanl.mx, arunasujanagcjgl@gmail.com
}

Received 6 April 2016; accepted 6 June 2016; published 9 June 2016

Copyright $@ 2016$ by authors and Scientific Research Publishing Inc.

This work is licensed under the Creative Commons Attribution International License (CC BY).

http://creativecommons.org/licenses/by/4.0/

(c) (i) Open Access

\section{Abstract}

The present study was undertaken in Forest Science Faculty, Universidad de Nuevo Leon, Mexico on variability of Wood density and its possible relation to few wood chemical composition and wood fiber cell structure anatomy. The results reveal that among 10 specie studied, there exist a large variation in wood density ( 0.51 to 1.09$)$, and few wood chemical composition such \% carbón (37.14 to 44.07), nitrogen (9.18 to 19.22 ), sulphur (31.45 to 33/82), lignin (15/28 to 24.35 ), hemicellulose (19.94 to $27.36 \%$ ), and \% cellulose (33.69 to 45.92$)$. In general, though there was no clear relationship between wood density and other chemical composition of wood. It was observed that the species having moderate to high wood density contained $>40 \%$ carbón, $>30 \%$ sulphur and $>\mathbf{4 0} \%$ cellulose and more or less $\mathbf{2 0 \%}$ lignin. It seems that carbón, sulphur, cellulose and lignin content contribute to greater density. The wood fiber cell with wall lignification seems to be related to higher wood density.

\section{Keywords}

Wood Density, Wood Chemical Composition, Cellulose, Lignin, Carbón Concentration, Variability

\section{Introduction}

Wood density is an important wood quality parameter in carbon cycle research and offers resistance in the trees against wind, storms, cavitation of xylem vessels, and other environmental stresses. The wood density of tropical 
tree species is determined in units of oven dry weight in grams per cubic centimeter of green volume. It varied from 0.5 to $0.8 \mathrm{~g} / \mathrm{cm}^{3}$ [1]. Few research findings are mentioned herein on wood density and factors affecting it. A study was undertaken [2] on wood density and fibre length of Eucalyptus grandis grown in Kerala, India in trees of four age groups ( $3,5,7$, and $9 \mathrm{yr}$ ). The average basic density was $495 \mathrm{~kg} / \mathrm{m}^{3}$ at $3 \mathrm{yr}$ revealing a no significant increase from 3 to $9 \mathrm{yr}$, whereas 5-yr-old trees had a significantly lower value. Density did not show significant differences but it differed significantly between the locations. The woof fibres were found to be longer in one location where the trees had a faster growth. It is well confirmed that wood-specific gravity is an important component of the biomass estimations [3] [4]. Wood density predicts life-history strategies of tree species, owing to the fact that it is closely related to tree growth rates [5]. On the other hand, wood density is positively related to drought resistance in tropical trees [6]-[8]. High wood density is positively correlated with xylem wall enforcement, which in turn reduces cavitation risk due to strong tensions during periods of drought [6]. It was reported [9] that the wood density of tree species in Neotropical forests was a taxonomically conserved trait, whereby variation in wood density was mainly explained by the wood density at generic level. Several studies on wood density have documented that community-level wood density varies considerably among Neotropical forests [9]-[11] and therefore it is considered a predictive variable in large-scale tropical biomass estimation protocols [9] [12], [13]. It is reported [11] that wood density across 59 Amazonian plots and four Neotropical forests, respectively, is negatively associated with soil fertility. In this respect at a broader scale, [10] (1988) undertook comparative study of North American and South American communities, and observed a positive correlation between wood density and mean annual precipitation. On the contrary, it was reported [14] that the variation in mean wood density within Guyana did not show correlation with either precipitation or soil fertility, whereas in Mexico, [15] found that mean wood density showed a negative correlation with precipitation. All these studies discuss contrasting trends in the regional and environmental variability of wood density, although they are based on a limited number of study sites or are restricted to one region of the Neotropics. Density is correlated with cavitationresistance. Wood density is safety factor against implosion of xylem to avoid collapse. It is investigated in [6]. A study was undertakent [16] on the relation between transport capacity and wood density and wood anatomy with leaf photosynthetic traits in two low land Panamanian forest. Leaf specific hydrauic conductivity of the upper branches showed positive corelation with the maximum rates of net $\mathrm{CO}_{2}$ assimilation per unit leaf area and stomatal conductivity. Maximum leaf hydraulic conductivity showed stronger correlation with net $\mathrm{CO}_{2}$ assimilation. This suggests that allocation to photosynthetic potential is proportional to maximum water transport. Branch wood density was negatively correlated with wood water storage and wood water potential. Wood density also constraints physiological functions.

A study was undertaken [17] on regional and phylogenetic variation of wood density across 2456 neotropical trees species. According to them, wood density is a crucial variable in carbon accounting programs of both secondary and old-growth tropical forests. Wood density is also the best single descriptor of wood: it correlates with numerous morphological, mechanical, physiological, and ecological properties. This reveals that genus-level means give reliable approximations of values of species, except in a few hypervariable genera. They also studied the evolutionary shifts in wood density occurring in the phylogeny of seed plants using a composite phylogenetic tree. Major changes occurred at deep nodes (Eurosid 1), and also in more recent divergences (for instance in the Rhamnoids, Simaroubaceae, and Anacardiaceae). Their unprecedented wood density data set yields consistent guidelines for estimating wood densities when species-level information is lacking and should significantly reduce error in Central and South American carbon accounting programs.

Wood density plays a key role in ecological strategies and life history variation in woody plants, but very little is known about its anatomical basis in shrubs [18]. They quantified the relationships between wood density, anatomy, and climate in 61 shrub species from eight field sites along latitudinal belts between 31 and 35 in North and South America. Measurements included cell dimensions, transverse areas of each xylem cell type and percentage contact between different cell types and vessels.

In the face of literatures available on various factors affecting wood density, a preliminary study is undertaken to find possible relation with few wood chemical composition and wood fiber characteristics.

\section{Materials and Methods}

Guadalupe Bárcenas Pazos and Raymundo Dávalos Sotelo (2015) (23) made a review on the importance of lignin. Temperate hardwood species, both from México and the United States undergo a greater shrinkage percen- 
tage than tropical hardwoods and softwoods from both countries. The three-dimensional stiffness of lignin, greater than that of the other chemical constituents of the cell wall, along with its low higroscopicity, relimit the movements due to changes in moisture content. Regression analyses to determine the influence of specific gravity and lignin content were analyzed. It is concluded that both have a marked importance. Specific gravity shows to be the most important variable, although the influence of lignin is also significant. It is remarked that it is necessary to carry out experimental studies on the effect of these variables on dimensional changes, along with that of other important variables, such as extractives and ray volume.

In earlier study we determined wood density of 37 woody species of Northeastern Mexico, out of which we selected 3 species with high density, 3 species with moderate density and 3 low density.

Wood samples of each species were grounded in a Thomas Willey mill (Thomas Scientific Apparatus, Model 3383) using a $\mathrm{N}^{\circ} 60(1 \mathrm{~mm} \times 1 \mathrm{~mm})$ mesh these were sieved, and stored in labeled plastic containers. Samples by triplicate were subjected to chemical analysis. The neutral detergent fibre (NDF), acid detergent fibre (ADF) and detergent fibre lignin (ADL) contents were determined by methods described by [19] VanSoest et al. (1991). Hemicellulose (NDF-ADF) and cellulose (ADF-lignin) were obtained by difference.

\section{Results and Discussion}

The Wood density variations and chemical composition of 10 woody species are shown in Table 1.

Wood density being an important parameter contributes to Wood quality. Various workers reported variation in Wood density in various species in the world [1] [2] [4] [6] [17] [20]. We also observed in the present study a large variation in Wood density. It is observed that among 9 species studied there existed a large variation in wood density which varied from (0.51 to 1.09), \% carbón (37.14 to 44.07), nitrogen (9.18 to 19.22), sulphur (31.04 to 33.82), lignin (15.28 to 24.35), hemicellulose (19.94 to 27.36\%), and \% cellulose (33.69 to 45.92). In general, though there was no clear relationship between wood density and other chemical composition of Wood. We observed the species having moderate to high wood density contained $>40 \%$ carbón, $>30 \%$ sulphur and $>40 \%$ cellulose and more or less $20 \%$ lignin. It seems that carbón, sulphur, cellulose and lignin content contribute to greater density. We do not observe clear cut relationship between lignin content with that in hard Wood. Wood fibre cells having lignified cell wall (being lignocellulose) contribute to density and strength to the Wood. The species having high wood density viz. Fraxinus greggii, Acacia shaffneri, Helietta parviflora contained in total $60 \%$ cellulose and lignin and 40\% carbón store revealing that apart from cellulose, and lignin carbón probably contribute to Wood density.

It has been interpreted by [21] that Wood anatomy could predict Wood quality and its utility. We wanted to verify this in the present study. We wanted to know whether Wood anatomical features could predict Wood density and Wood quality interpreted by [21]. It is observed that tree species having high Wood density have compact Wood tissue with thick walled Wood fibres as observed in the case of Hellieta parviflora shown below.

Table 1. Variability in wood density $\left(\mathrm{g} / \mathrm{cm}^{3}\right)$, \% of carbón, nitrogen,sulphur, lignin, hemicellulose, and cellulose in ten Woody species.

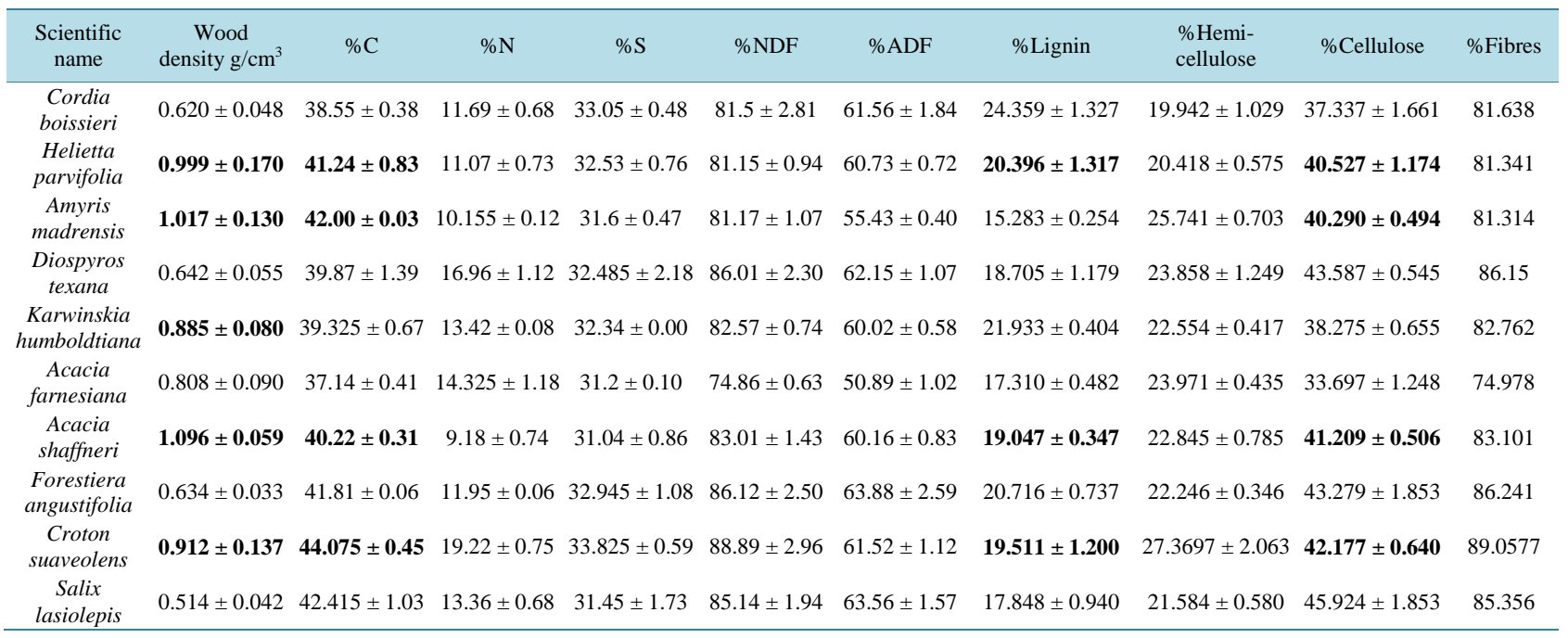




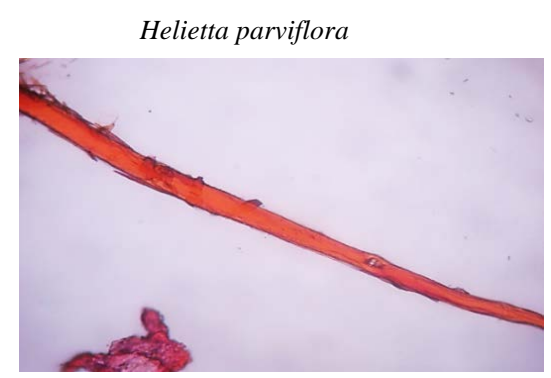

Wood fiber cell

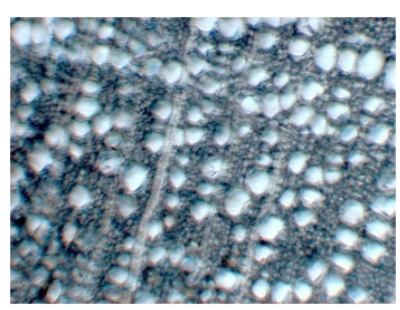

Transverse section of wood

We also observed that both Acacia shaffneri and Fraxinus greggii having high Wood density have thick walled fibre cell and narrow lumen.

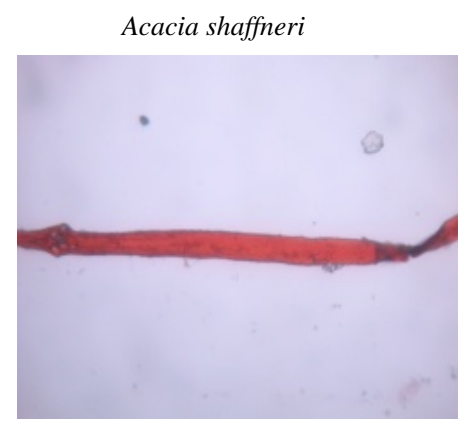

Wood fiber cell

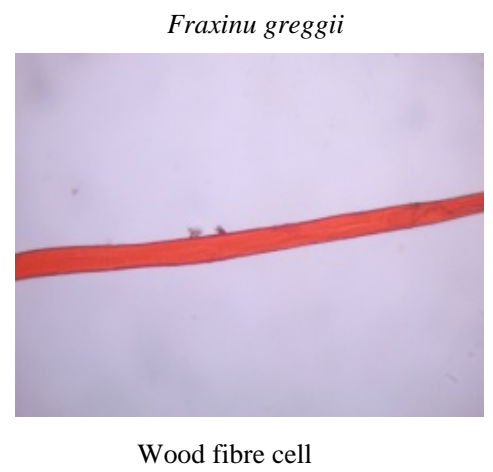

On the contrary in the case of soft wood Salix humboldtiana, Forestieria angustifolia and Cordia boissieri, the Wood tissue is loose and fibre cells are thin walled with broad lumen as shown below.

SOFT WOOD

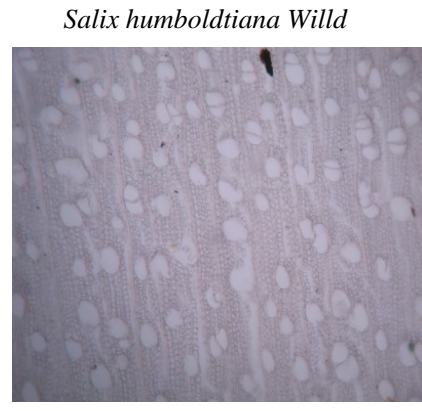

Transverse section

Forestiera angustifolia Torr.

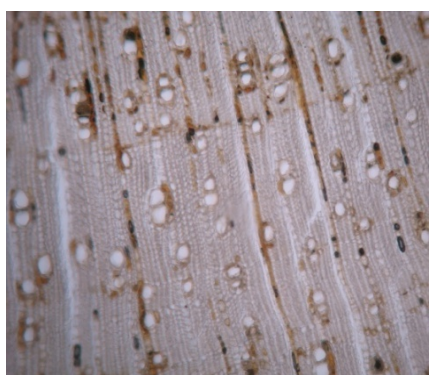

Transverse section

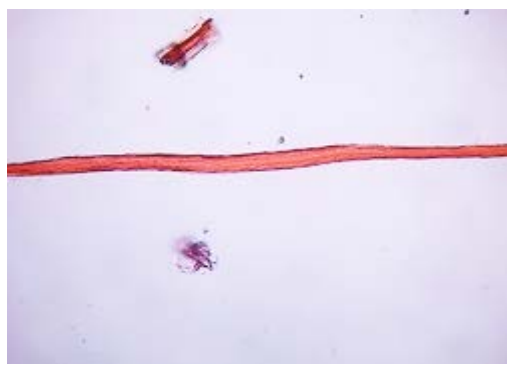

Fiber cell 40×

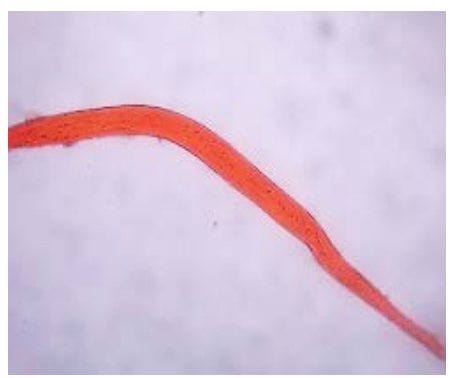

Fibre cell 40× 


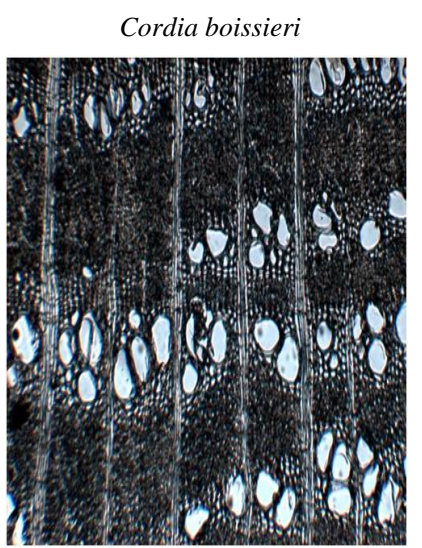

Transverse section

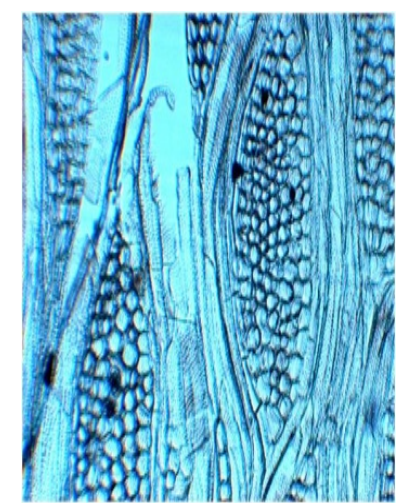

Tangential section

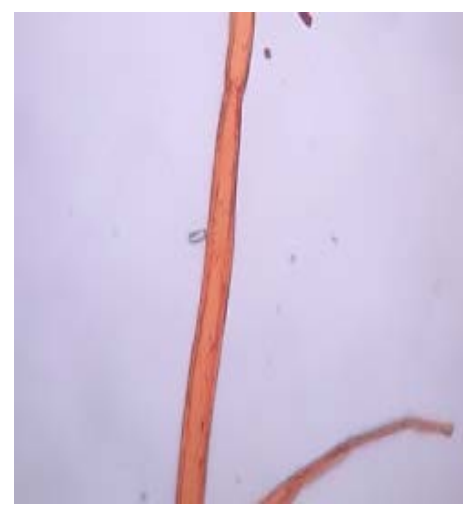

Fiber cell 40×

It is observed the species having high Wood density (Acacia shaffneri, Fraxinusgreggii, Helietaparviflora) possess compact Wood with thick walled fibre cells, thick walled cell wall and narrow lumen compared to soft wood having loose wood tissue, thin fibre cell wall viz. Salix humboldtiana, Forestieria angustifolia, Cordia boissieri. This needs to be confirmed in future study.

\section{Conclusion}

The present study has clearly shown that the chemical composition of the woody tree species varies. This variability in the percent carbon content, ligin, sulphur and hemicellulose may govern the variability in the wood density of the species also as these form the major weight in determining the oven dry weight of the species during the determination of wood density. It was observed that the species in high density had lignified fibre cell wall and compact wood. It has been observed that this variability in the chemical composition is also likely to determine the fiber lumen width and the density of the fibres. This hypotheses needs further confirmation. This needs to be confirmed with a large number of species.

\section{References}

[1] Reyes, G., Brown, S., Chapman, J. and Lugo, A.E. (1992) Wood Densities of Tropical Tree Species. General Technical Report SO-88. USDA Forest Service, Southern Forest Experiment Station, New Orleans.

[2] Bhat, K.M., Bhat, K.V. and Dhamodaran, T.K. (1990) Remove from marked Records Wood Density and Fibre Length of Eucalyptus grandis Grown in Kerala, India. Wood and Fiber Science, 22, 54-61.

[3] Magcale-Macandog, D.B. (2004) Comparative Evaluation of Different Approaches to Estimate Aboveground Biomass and Biomass Density of Tropical Forests in Southeast Asia: A Review. The Philippine Agricultural Scientist, 87, 6175.

[4] Noguera, E.M., Nelson, B.W. and Fearnside, P.M. (2005) Wood Density in Dense Forest in Central Amazonia, Brazil. Forest Ecology and Management, 208, 261-286. http://dx.doi.org/10.1016/j.foreco.2004.12.007

[5] King, D. and Mandonald, J. (1999) Tree Architecture in Relation to Leaf Dimensions and Tree Stature in Relation to Leaf Dimensions and Tree Stature in Temperate and Tropical Rain Forests. Journal of Ecology, 87, 1012-1024. http://dx.doi.org/10.1046/j.1365-2745.1999.00417.x

[6] Hacke, U.G., Sperry, J.S., Pockman, W.T., Davis, S.D. and McCulloh, K.A. (2001) Trends in Wood Density and Structure Are Linked Prevention of Xylem Implosion Bynegative Pressure. Oceologia, 126, 457-461. http://dx.doi.org/10.1007/s004420100628

[7] Meinzer, F.C. (2003) Functional Convergence in Plant Responses to the Environment. Oecologia, 134, 1-11. http://dx.doi.org/10.1007/s00442-002-1088-0

[8] Slik, J.W.F. (2004) El Nino Droughts and Their Effects on Tree Species Composition and Diversity in Tropical Rainforests. Oecologia, 141, 114-120. http://dx.doi.org/10.1007/s00442-004-1635-y

[9] Baker, T.R., Phillips, O.L., Malhi, Y., Almeida, S., Arroyo, L., Di Fiore, A., Erwin, T., Killeen, T.J. and Laurance, S.G. (2004) Variation in Wood density Determines Spatial Patterns in Amazonian Forest Biomass. Global Change Biology, 10, 545-562. http://dx.doi.org/10.1111/j.1365-2486.2004.00751.x 
[10] Wiemann, M.C. and Williamson, G.B. (1988) Extreme Radial Changes in Wood Specific Gravity in Some Tropical Pioneers. Wood Fiber Science, 20, 344-349.

[11] Muller-Landau, H.C. (2004) Interspecific and Intersite Variation in Wood Specific Gravity of Tropical Trees. Biotropica, 36, 20-32.

[12] DeWalt, S.J. and Chave, J. (2004) Structure and Biomass of Four Lowland Neotropical Forests. Biotropica, 36, 7-19. http://dx.doi.org/10.1111/j.1744-7429.2004.tb00291.x

[13] Chave, J., Condit, R., Aguilar, S., Hernandez, A., Lao, S. and Chave, J. (2005) Tree Allometry and Improved Estimation of Carbon Stocks and Balance in Tropical Forests. Oecologia, 145, 87-99. http://dx.doi.org/10.1007/s00442-005-0100-x

[14] Steege, H. and Hammond, D.S. (2001) Character Convergence, Diversity, and Disturbance in Tropical Rain Forest in Guyana. Ecology, 82, 3197-3212. http://dx.doi.org/10.1890/0012-9658(2001)082[3197:CCDADI]2.0.CO;2

[15] Barajas-Morales, J. (1987) Wood specific Gravity in Species from Two Tropical Forests in Mexico. IAWA Journal, 8, 143-148. http://dx.doi.org/10.1163/22941932-90001041

[16] Santiago, L.S., Goldstein, G., Meinzer, F.C., Fisher, J.B., Machad, K. and Jones, T. (2004) Leaf Photosynthesis Traits Scale with Hydraulic Conductivity and Wood Density in Panamanian Forest Tress. Ocelogia, 140, 543-550. http://dx.doi.org/10.1007/s00442-004-1624-1

[17] Chave, J., Muller-Landau, H.C., Baker, T.R., Easdale, T.A., Steege, H. and Webb, C.O. (2006) Regional and Phylogenetic Variation of Wood Density across 2456 Neotropical Trees Species. Ecological Applications, 16, 2356-2367. http://dx.doi.org/10.1890/1051-0761(2006)016[2356:RAPVOW]2.0.CO;2

[18] Martínez-Cabrera, H.I., Jones, C.S., Espino, S. and Schenk, H.J. (2009) Wood Anatomy and Wood Density in Shrubs Responses to Varying Aridity along Transcontinental Transects. American Journal of Botany, 96, 1388-1398. http://dx.doi.org/10.3732/ajb.0800237

[19] Van Soest, P.J., Robertson, J.B. and Lewis, B.A. (1991) Methods for Dietary, Neutral Detergent Fiber and Nonstarch Polysaccharides in Relation to Animal Nutrition. Symposium: Carbohydrate Methodology, Metabolism and Nutritional Implications in Diary Cattle. Journal of Dairy Science, 74, 3583-3597. http://dx.doi.org/10.3168/jds.S0022-0302(91)78551-2

[20] Martinez, V.M.R. (2004) Variation in Wood Density Deter-Mines Spatial Patterns in Amazonian Forest Biomass. Global Change Biology, 10, 545-562. http://dx.doi.org/10.1111/j.1365-2486.2004.00751.x

[21] Maiti, R.K and Rodriguez, H.G. (2015) Wood Anatomy Could Predict the Adaption of Woody Plants to Environmental Stresses and Quality of Timbers. Forest Research, 4, 4. http://dx.doi.org/10.4172/2168-9776.1000e121 